\title{
Thermal behavior in oxidative and pyrolysis conditions and characterization of some metal p-aminobenzoate compounds using TG-DTA, EGA and DSC- photovisual system
}

\author{
J.A. Teixeira ${ }^{a}$, W.D.G. Nunes ${ }^{a}$, R.P. Fernandes ${ }^{a}$, A.L.C.S. do Nascimento ${ }^{a}$, F.J. Caires ${ }^{b}$, \\ M. Ionashiro ${ }^{\text {, }}$ \\ a São Paulo State University (UNESP), Institute of Chemistry, Araraquara, SP, Brazil \\ b São Paulo State University (UNESP), School of Science, Bauru, SP, Brazil
}

\section{A R T I C L E I N F O}

\section{Keywords:}

Bivalent transition metals

p-aminobenzoates

Thermal behavior

Pyrolysis

Evolved gases

\begin{abstract}
A B S T R A C T
Synthesis, thermal and spectroscopic study of solid bivalent transition metal compounds of Mn(II), Co(II), Ni(II), $\mathrm{Cu}(\mathrm{II})$ and $\mathrm{Zn}$ (II) with p-aminobenzoate as ligand were performed. The thermal study was performed in oxidative and pyrolysis conditions, using the thermoanalytical techniques: Simultaneous thermogravimetry and differential thermal analysis (TG-DTA), differential scanning calorimetry (DSC), DSC-photovisual system and evolved gas analysis (EGA) by TG/DSC-FTIR. Infrared absorption spectroscopy (FTIR) and powder X-ray diffractometry (PXRD) were employing in the spectroscopic study. The general formula $\mathrm{M}(\mathrm{L})_{2} \cdot \mathrm{nH}_{2} \mathrm{O}$ has been established by TGDTA, elemental analysis and complexometry with EDTA, where $\mathrm{M}$ represents $\mathrm{Mn}, \mathrm{Co}, \mathrm{Ni}, \mathrm{Cu}$ and $\mathrm{Zn}, \mathrm{L}$ is paminobenzoate and $\mathrm{n}=0(\mathrm{Mn}, \mathrm{Co}), 1(\mathrm{Ni}), 1.5(\mathrm{Zn}), 2(\mathrm{Cu})$. In oxidative condition (dry air atmosphere), the thermal decomposition occurred in one, two or three steps, with formation of the respective oxides $\left(\mathrm{Mn}_{3} \mathrm{O}_{4}, \mathrm{CoO}\right.$, $\mathrm{NiO}, \mathrm{CuO}$ and $\mathrm{ZnO})$. Under pyrolysis condition $\left(\mathrm{N}_{2}\right.$ atmosphere), the thermal decomposition occurred in three or four steps, with mass loss still being observed up to $1000^{\circ} \mathrm{C}$. DSC-photovisual system curves provided information about of the dehydration and phase transformation processes, as well as their enthalpies. The EGA data allowed the identification of gaseous products evolved during pyrolysis and oxidative decomposition. The results of the FTIR and PXRD also provided information on the ligand's denticity and crystallinity of the compounds.
\end{abstract}

\section{Introduction}

4-aminobenzoic acid or p-aminobenzoic acid (H-pABA), whose molecular formula is $\mathrm{C}_{7} \mathrm{H}_{7} \mathrm{NO}_{2}$ with molar mass of $137.14 \mathrm{~g} \mathrm{~mol}^{-1}$, is a cyclic amino acid that belong to a great group of biologically significant aromatic compounds. It's obtained as a crystalline powdered white/white-yellowish needles, also known as vitamin $\mathrm{Bx}$, frequently found in food, produced by essential symbiotic bacteria and is metabolized constantly in our bodies [1-3]. H-pABA is a precursor of folic acid and in high concentrations has been studied in the inhibition of bacteria and viruses, showing anticoagulant, antioxidant and immunomodulatory properties. In vivo and in vitro assays have demonstrated efficacy in the treatment of ocular viral herpes, primarily related to its capacity to induce the synthesis of endogenous interferon in the human body $[2,3]$. In recent years, transition metal complexes with molecules that have biochemical properties, such as amino acids, benzoic acids derivatives and others organic substances have been reported as biomarkers and new drugs, in catalysis and as luminescent material [4-14].
The literature contains reports of the thermal behavior and spectroscopic study of aminobenzoic acid coordination compounds with lanthanide ions and yttrium $[15,16]$. However, no previous work has been reported on about systematical thermoanalytical study of compounds formed of by paminobenzoic acid/p-aminobenzoate with the Mn(II), Co(II), Ni(II), Cu(II) and Zn(II) ions in pyrolysis and oxidative conditions. Thus, the present study describes the synthesis, characterization and thermoanalytical study of these compounds. The characterization was performed using thermoanalytical techniques (TG-DTA, DSC, EGA) and complementary techniques (complexometry with EDTA, elemental analysis, powder X-ray diffraction (PXRD) and infrared spectroscopy (FTIR)).

\section{Experimental}

\subsection{Synthesis}

The $p$-aminobenzoic acid (H-pABA, C7H7NO2) with 99\% purity was

\footnotetext{
* Corresponding author.

E-mail address: massaoi@yahoo.com.br (M. Ionashiro).
} 
obtained from Sigma and it was used as received. Bivalent manganese, cobalt, nickel, copper and zinc carbonates were prepared by adding slowly with continuous stirring saturated sodium hydrogen carbonate solution $\left(0.1 \mathrm{~mol} \mathrm{~L}^{-1}\right)$ to the corresponding metal chlorides or sulphate copper solutions $\left(50.0 \mathrm{~mL}, 0.1 \mathrm{~mol} \mathrm{~L}^{-1}\right)$ until total precipitation of the metal ions. The precipitates were washed with distilled water until the elimination of chloride or sulphate ions (qualitative test with $\mathrm{AgNO}_{3}$ / $\mathrm{HNO}_{3}$ solution for chloride and $\mathrm{BaCl}_{2}$ solution for sulphate) and maintained in aqueous suspension. Solid-state $\mathrm{Mn}(\mathrm{II}), \mathrm{Co}(\mathrm{II}), \mathrm{Ni}(\mathrm{II}), \mathrm{Cu}$ (II) and Zn(II) compounds were prepared by mixing the corresponding metal carbonate aqueous suspension with $110 \mathrm{~mL}$ (slight excess) of aqueous suspension p-aminobenzoic acid $0.1 \mathrm{~mol} \mathrm{~L}^{-1}$, and heated slowly to near ebullition, until neutralization of the acid. The solutions with the precipitates were maintained at ambient temperature, filtered and washed with ethanol to eliminate the possible presence of p-aminobenzoic acid added in excess. The solid was then dried at $50{ }^{\circ} \mathrm{C}$ in a forced circulation air oven for $12 \mathrm{~h}$ and kept in a desiccator over anhydrous calcium chloride.

\subsection{Experimental equipment and conditions}

In the solid-state, metal ions, hydration water and stoichiometry were determined from TG curves. The metal ions were also determined by complexometry with standard EDTA solutions after igniting the compounds to the respective oxides and their dissolution in hydrochloric acid solution $[17,18]$.

Carbon, hydrogen and nitrogen contents were determined by microanalytical procedures, with a CHN Elemental Analyzer from Perkin Elmer, model 2400.

X-ray powder patterns were obtained by using a Rigaku MiniFlex 600 X-Ray Diffractometer employing CuKa radiation $(\lambda=1.54056 \AA)$ and setting of $40 \mathrm{KV}$ and $15 \mathrm{~mA}$.

Infrared spectra were obtained by using a Nicolet iS10 FTIR spectrophotometer, using ATR accessory with Ge window. The FTIR spectra were recorded with 32 scans per spectrum at resolution of $4 \mathrm{~cm}^{-1}$.

Simultaneous TG-DTA and DSC curves were obtained with two thermal analysis systems, model SDT 2960 and Q10 respectively both from TA Instruments. The purge gas was dry air or nitrogen, for TGDTA, and nitrogen for DSC both at a flow rate of $100 \mathrm{~mL} \mathrm{~min}^{-1}$. A heating rate of $10{ }^{\circ} \mathrm{C} \mathrm{min}^{-1}$ was adopted, with samples weighing about $10 \mathrm{mg}$ for TG-DTA and $2 \mathrm{mg}$ for DSC. Alumina and aluminum crucibles, the latter with perforated cover, were used for recording the TG-DTA and DSC curves, respectively.

The images were obtained on equipment Mettler-Toledo DSC 1 stare system coupled to OLYMPUS digital camera; model SC 30 which incorporates a 3.3 megapixel CMOS sensor, optical sub-assembly mechanic Navitar 1-6232D with $6.5 \times$ zoom. The experimental conditions were similar to those used to obtain the DSC curve.

The identification of evolved gases (EGA) in dynamic dry air and nitrogen atmospheres were carried out using a TG-DSC 1 Mettler Toledo coupled to a Nicolet FTIR spectrophotometer with gas cell and DTGS detector, with $\mathrm{KBr}$ windows. The furnace and heated gas cell $\left(250^{\circ} \mathrm{C}\right)$ were coupled through a heated $\left(225^{\circ} \mathrm{C}\right) 120 \mathrm{~cm}$ stainless steel transfer line with diameter of $3.0 \mathrm{~mm}$, both purged with dry air and nitrogen $\left(50 \mathrm{~mL} \mathrm{~min}^{-1}\right)$. The FTIR spectra were recorded with 16 scans per spectrum at a resolution of $4 \mathrm{~cm}^{-1}$.

\section{Results and discussion}

The analytical and thermoanalytical (TG) results are shown in Table 1. These results permitted to establish the stoichiometry of the compounds, which are in agreement with the general formula: $\mathrm{M}$ $(\mathrm{L})_{2} \cdot \mathrm{nH}_{2} \mathrm{O}$, where $\mathrm{M}$ represents $\mathrm{Mn}, \mathrm{Co}, \mathrm{Ni}, \mathrm{Cu}$ and $\mathrm{Zn}, \mathrm{L}$ is p-aminobenzoate and $\mathrm{n}=0(\mathrm{Mn}, \mathrm{Co}), 1(\mathrm{Ni}), 1.5(\mathrm{Zn}), 2(\mathrm{Cu})$.

The TG-DTA curves of the compounds in dynamic dry air and nitrogen atmospheres are shown in Fig. 1a-e (air) and $\mathrm{f}-\mathrm{j}\left(\mathrm{N}_{2}\right)$, respectively. These curves show mass losses in one (Mn), two (Co, Ni, $\mathrm{Cu}$ ) and three ( $\mathrm{Zn})$ steps (air) or three ( $\mathrm{Mn}, \mathrm{Co}$ ) and four (Ni, Cu, $\mathrm{Zn}$ ) steps $\left(\mathrm{N}_{2}\right)$ and thermal events corresponding to the losses.

The thermal stability of hydrated (I) and anhydrous (II) compounds in air and nitrogen atmosphere, as well as the final temperature of thermal decomposition (III) in air, as shown by the TG-DTA curves, depends on the nature of the metal ion and atmosphere used and they follow the order:

\begin{tabular}{ll}
\hline Air atmosphere & $\mathrm{N}_{2}$ atmosphere \\
\hline (I) $\mathrm{Cu}>\mathrm{Ni}>\mathrm{Zn}$ & (I) $\mathrm{Cu}>\mathrm{Ni}>\mathrm{Zn}$ \\
(II) $\mathrm{Mn}>\mathrm{Zn}>\mathrm{Co}>\mathrm{Ni}>\mathrm{Cu}$ & $\begin{array}{l}\text { (II) } \mathrm{Mn}>\mathrm{Co}=\mathrm{Ni}=\mathrm{Zn}> \\
\mathrm{Cu}\end{array}$ \\
(III) $\mathrm{Mn}>\mathrm{Co}=\mathrm{Ni}>\mathrm{Zn}>\mathrm{Cu}$ & \\
\hline
\end{tabular}

In air atmosphere a great similarity is noted concerning the TG profiles of the manganese and cobalt compounds, Fig. 1(a, b), as well as of the nickel and copper one, Fig. 1(c,d). On the other hand, zinc compound display another TG-DTA profile, Fig. 1(e).

For $\mathrm{N}_{2}$ atmosphere, the similarity is also noted in the TG profiles of the manganese and cobalt compounds or nickel and zinc ones, while copper compounds display a different TG profile. Thus, the TG-DTA curves in each atmosphere are presented separately and the features of each of these compounds are discussed bases on its similar thermal profiles.

\subsection{TG-DTA in dry air atmosphere}

\subsubsection{Manganese and cobalt compounds}

The TG-DTA curves of these compounds are shown in Fig. 1(a and b). These curves show that both compounds were obtained in the anhydrous state, and stable up to $330{ }^{\circ} \mathrm{C}(\mathrm{Mn})$ or $300{ }^{\circ} \mathrm{C}(\mathrm{Co})$ and the thermal decomposition occurs in a single step up to $425{ }^{\circ} \mathrm{C}(\mathrm{Mn})$ and $410{ }^{\circ} \mathrm{C}(\mathrm{Co})$, with losses of $76.96 \%$ and $75.65 \%$, respectively. In correspondence with the mass loss, the DTA curve exhibits a large and sharp exothermic peak at $400{ }^{\circ} \mathrm{C}(\mathrm{Mn}, \mathrm{Co})$, attributed to oxidation of the organic matter and/or of the gaseous products evolved during the thermal decomposition. The total mass loss up to $425^{\circ} \mathrm{C}(\mathrm{Mn})$ and $410{ }^{\circ} \mathrm{C}$ (Co) are in agreement with the formation of $\mathrm{Mn}_{3} \mathrm{O}_{4}$ (Calcd. $=23.31 \%$, TG $=23.15 \%$ ) and $\mathrm{Co}_{3} \mathrm{O}_{4}$ (Calcd. $=24.23 \%$, T$\mathrm{G}=24.40 \%$ ) as final residue, respectively. For the cobalt compound, the last small mass loss between 920 and $950{ }^{\circ} \mathrm{C}$, corresponding to an endothermic peak at $930{ }^{\circ} \mathrm{C}$ is attributed to reduction reaction of $\mathrm{Co}_{3} \mathrm{O}_{4}$ to $\mathrm{CoO}$ (Calcd. $1.60 \%$, TG $=1.50 \%$ ) [4].

\subsubsection{Nickel and copper compounds}

The TG-DTA curves are shown in Fig. 1(c and d), respectively. The first mass loss between 70 and $160{ }^{\circ} \mathrm{C}(\mathrm{Ni})$ and $95-185^{\circ} \mathrm{C}(\mathrm{Cu})$, corresponding to an endothermic peak at $135{ }^{\circ} \mathrm{C}$ and $170{ }^{\circ} \mathrm{C}$, respectively, is attributed to dehydration with loss of 1 (Ni) and $2(\mathrm{Cu}) \mathrm{H}_{2} \mathrm{O}$ (Calcd. $=5.16 \%, 9.19 \%$; $\mathrm{TG}=5.22 \%, 9.98 \%$ ).

The anhydrous compounds are stable up to $295^{\circ} \mathrm{C}(\mathrm{Ni})$ and $240{ }^{\circ} \mathrm{C}$ (Cu) and above this temperature the mass loss occurs in a single step up to $410{ }^{\circ} \mathrm{C}(\mathrm{Ni})$ and $340{ }^{\circ} \mathrm{C}(\mathrm{Cu})$ with loss of 73.67 and $68.85 \%$, respectively. In correspondence with the mass loss, the DTA curve shows a large and sharp exothermic peak attributed to the oxidation of organic matter and/or gaseous products evolved during the thermal decomposition. The total mass loss up to $410{ }^{\circ} \mathrm{C}(\mathrm{Ni})$ and $340{ }^{\circ} \mathrm{C}(\mathrm{Cu})$ is in agreement with the formation of $\mathrm{NiO}$ (Calcd. $=21.41 \%$, $\mathrm{TG}=21.30 \%$ ) and $\mathrm{CuO}$ (Calcd. $=21.39 \% ; \mathrm{TG}=21.25 \%$ ), as final residue.

\subsubsection{Zinc compound}

The TG-DTA curves are shown in Fig. 1(e). The first mass loss 
Table 1

Analytical and thermoanalytical $\left(\mathrm{TG}^{\mathrm{a}}\right)$ results for $\mathrm{M}(\mathrm{L})_{2} \cdot \mathrm{nH}_{2} \mathrm{O}$ compounds.

\begin{tabular}{|c|c|c|c|c|c|c|c|c|c|c|c|c|c|c|c|c|c|}
\hline \multirow[t]{2}{*}{ Compounds } & \multicolumn{3}{|c|}{ Ln (oxide) $/ \%$} & \multicolumn{2}{|c|}{ L (Lost)/\% } & \multicolumn{2}{|c|}{ Water/\% } & \multicolumn{3}{|l|}{$\mathrm{C} / \%$} & \multicolumn{3}{|l|}{$\mathrm{N} / \%$} & \multicolumn{3}{|l|}{$\mathrm{H} / \%$} & \multirow[t]{2}{*}{ Final Residue } \\
\hline & Calcd. & EDTA & TG & Calcd. & TG & Calcd. & TG & Calcd. & EA & TG & Calcd. & EA & TG & Calcd. & EA & TG & \\
\hline $\operatorname{Mn}(\mathrm{L})_{2}$ & 23.31 & 23.15 & 23.04 & 76.69 & 76.96 & - & - & 44.04 & 44.49 & 44.20 & 8.56 & 8.99 & 8.59 & 3.70 & 3.05 & 3.71 & $\mathrm{Mn}_{3} \mathrm{O}_{4}$ \\
\hline $\mathrm{Co}(\mathrm{L})_{2}$ & 24.23 & 24.40 & 24.35 & 75.77 & 75.65 & - & - & 43.51 & 43.16 & 43.44 & 8.46 & 9.11 & 8.45 & 3.66 & 3.11 & 3.65 & $\mathrm{Co}_{3} \mathrm{O}_{4}$ \\
\hline $\mathrm{Ni}(\mathrm{L})_{2} \cdot \mathrm{H}_{2} \mathrm{O}$ & 21.41 & 21.30 & 21.11 & 73.43 & 73.67 & 5.16 & 5.22 & 41.29 & 41.04 & 41.44 & 8.03 & 8.42 & 8.06 & 4.05 & 4.58 & 4.07 & $\mathrm{NiO}$ \\
\hline $\mathrm{Cu}(\mathrm{L})_{2} \cdot 2 \mathrm{H}_{2} \mathrm{O}$ & 21.39 & 21.25 & 21.17 & 68.92 & 68.85 & 9.69 & 9.98 & 38.76 & 38.15 & 38.87 & 7.53 & 6.98 & 7.55 & 4.32 & 4.60 & 4.36 & $\mathrm{CuO}$ \\
\hline $\mathrm{Zn}(\mathrm{L})_{2} \cdot 1.5 \mathrm{H}_{2} \mathrm{O}$ & 22.31 & 22.40 & 22.15 & 70.28 & 70.62 & 7.41 & 7.23 & 39.52 & 40.07 & 39.60 & 7.68 & 7.16 & 7.70 & 4.16 & 3.85 & 4.17 & $\mathrm{ZnO}$ \\
\hline
\end{tabular}

$\mathrm{L}=p$-aminobenzoate, $\mathrm{n}=$ number water molecules.

a $\mathrm{TG}$ in air atmosphere.
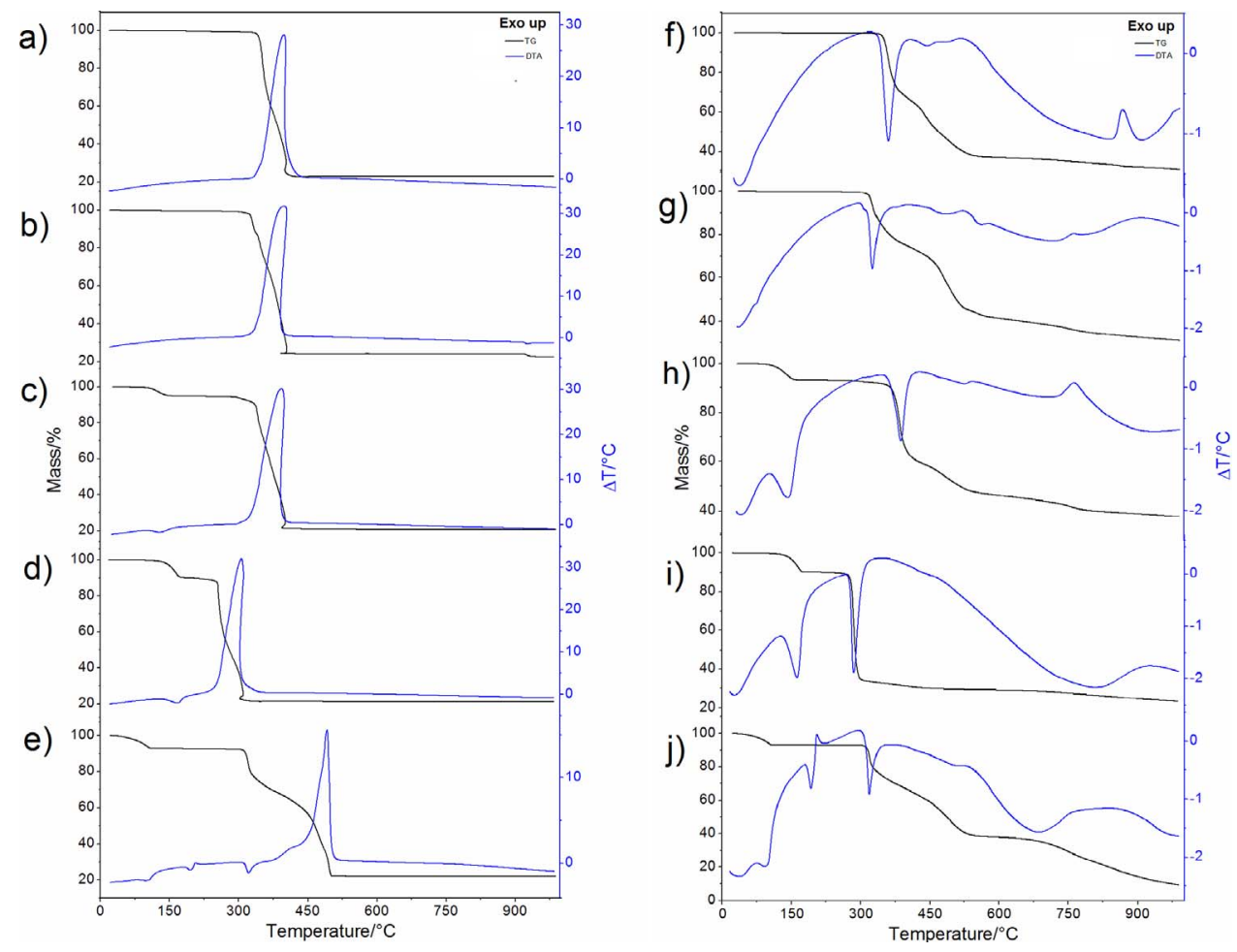

Fig. 1. TG-DTA curves of the compounds in dynamic dry air (a-e) and $\mathrm{N}_{2}$ (f-j) atmospheres: (a) $\mathrm{Mn}(\mathrm{L})_{2}$ (m = $10.0529 \mathrm{mg})$; (b) $\mathrm{Co}(\mathrm{L})_{2}(\mathrm{~m}=10.0004 \mathrm{mg})$; (c) $\mathrm{Ni}(\mathrm{L})_{2} \cdot \mathrm{H}_{2} \mathrm{O}(\mathrm{m}=10.0968 \mathrm{mg})$; (d) $\mathrm{Cu}(\mathrm{L})_{2} \cdot 2 \mathrm{H}_{2} \mathrm{O}$ (m $=10.0061 \mathrm{mg}) ; \quad$ (e) $\quad \mathrm{Zn}(\mathrm{L})_{2} \cdot 1.5 \mathrm{H}_{2} \mathrm{O} \quad$ (m = $10.0419 \mathrm{mg}$ ); (f) $\mathrm{Mn}(\mathrm{L})_{2}$ (m = $10.0319 \mathrm{mg}$ ); (g) Co $(\mathrm{L})_{2} \quad(\mathrm{~m}=10.0275 \mathrm{mg}) ; \quad$ (h) $\quad \mathrm{Ni}(\mathrm{L})_{2} \cdot \mathrm{H}_{2} \mathrm{O} \quad(\mathrm{m}=$ $10.0207 \mathrm{mg}$ ); (i) $\mathrm{Cu}(\mathrm{L})_{2} \cdot 2 \mathrm{H}_{2} \mathrm{O}(\mathrm{m}=9.9928 \mathrm{mg}$ ) and (j) $\mathrm{Zn}(\mathrm{L})_{2} \cdot 1.5 \mathrm{H}_{2} \mathrm{O}(\mathrm{m}=10.3032 \mathrm{mg})$.

between 30 and $110{ }^{\circ} \mathrm{C}$, corresponding to an endothermic peak at $105^{\circ} \mathrm{C}$ is attributed to dehydration with loss of $1.5 \mathrm{H}_{2} \mathrm{O}$ (Calcd. $=7.41 \%$; $\mathrm{TG}=7.23 \%$ )

The anhydrous compound is stable up to $305^{\circ} \mathrm{C}$ and above this temperature the mass loss occurs in two consecutive steps between 305 and $370{ }^{\circ} \mathrm{C}$ and $370-510{ }^{\circ} \mathrm{C}$ with loss of $22.20 \%$ and $42.42 \%$, corresponding to a small endothermic peak at $325{ }^{\circ} \mathrm{C}$ attributed to the thermal decomposition and a large and sharp exothermic peak at $495{ }^{\circ} \mathrm{C}$ attributed to oxidation of the organic matter and/or of the gaseous products evolved during the thermal decomposition. The total mass loss up to $510^{\circ} \mathrm{C}$ is in agreement with the formation of $\mathrm{ZnO}$ (Calcd. $=22.31 \%$; $\mathrm{TG}=22.40 \%$ ), as final residue. The small endothermic and exothermic peaks at $195{ }^{\circ} \mathrm{C}$ and $210{ }^{\circ} \mathrm{C}$, without mass loss in the TG curve were attributed to melting and recrystallization, respectively. The fusion and recrystallization were confirmed by DSCPhotovisual system. In the images, it is possible to visualize the melting of the material, followed by its recrystallization (see Fig. 2(e) and video in supplementary material).

\subsection{TG-DTA in $N_{2}$ atmosphere}

\subsubsection{Manganese and cobalt compounds}

The TG-DTA curves of manganese and cobalt compounds are shown in Fig. 1(f and g), respectively. These curves show that the compounds are anhydrous and stable up to $335^{\circ} \mathrm{C}(\mathrm{Mn})$ and $300{ }^{\circ} \mathrm{C}(\mathrm{Co})$ and above this temperature the thermal decomposition occurs in three consecutive steps, between 335 and $395^{\circ} \mathrm{C}, 395-560^{\circ} \mathrm{C}$ and $560>1000{ }^{\circ} \mathrm{C}$, with losses of $31.71,30.70$ and $6.34 \%$ for $\mathrm{Mn}$ and $24.73,32.33$ and $11.98 \%$ for $\mathrm{Co}$, respectively. In correspondence with the mass losses which are still being observed up to $1000^{\circ} \mathrm{C}$, the DTA curves show endothermic peaks at $365^{\circ} \mathrm{C}, 445^{\circ} \mathrm{C}, 495^{\circ} \mathrm{C}$, (Mn) and $330{ }^{\circ} \mathrm{C}, 480{ }^{\circ} \mathrm{C}, 560{ }^{\circ} \mathrm{C}$, (Co), attributed to the thermal decomposition of the compounds. The last step of mass loss in the TG curves, associated to the exothermic peaks at $867{ }^{\circ} \mathrm{C}(\mathrm{Mn})$ and $762{ }^{\circ} \mathrm{C}(\mathrm{Co})$, is attributed to the pyrolysis and reaction of carbonaceous residue with manganese and cobalt oxides that lead to a partial reduction (endo) of $\mathrm{MnxOy}$ to $\mathrm{MnO}$ and $\mathrm{CoxOy}$ to $\mathrm{CoO}$ and oxidation (exo) of carbonaceous residue to $\mathrm{CO}_{2}$, resulting in an exothermic balance in the DTA curve $[19,20]$. The EGA analysis in dynamic $\mathrm{N}_{2}$ atmosphere shown the presence of the $\mathrm{CO}_{2}$ up to $867^{\circ} \mathrm{C}(\mathrm{Mn})$ and $762{ }^{\circ} \mathrm{C}$, as the indicated by the DTA curves, see Figs. $3 \mathrm{~S}$ and $4 \mathrm{~S}$ in the supplementary material.

For de cobalt compound, is observed an indicative of the endothermic event in DTA curve at $77^{\circ} \mathrm{C}$, without mass loss in TG attributed to reversible phase transition. The reversible phase transition was confirmed by heating and cooling DSC curve (see Fig. 1S in the supplementary material). 

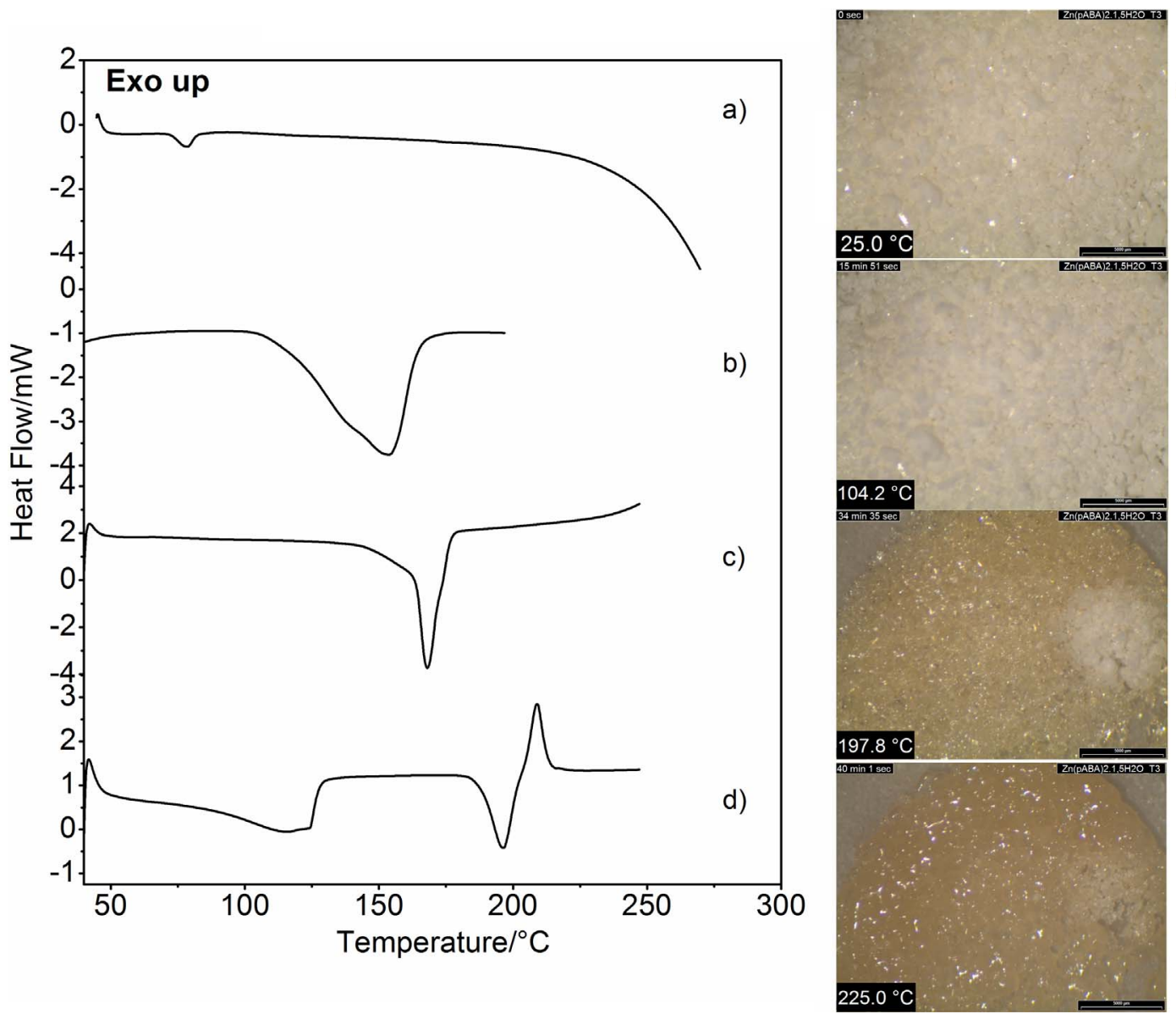

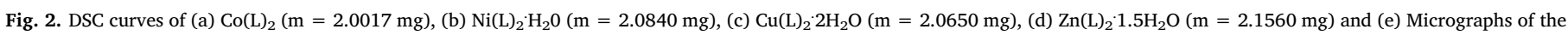
zinc compound at different temperatures.

\subsubsection{Nickel and zinc compounds}

The TG-DTA curves are shown in Fig. 1(h and j). The first mass loss between 90 and $160{ }^{\circ} \mathrm{C}(\mathrm{Ni})$ and $30-115^{\circ} \mathrm{C}(\mathrm{Zn})$ corresponding to an endothermic peak at $145{ }^{\circ} \mathrm{C}(\mathrm{Ni})$ and $100{ }^{\circ} \mathrm{C}(\mathrm{Zn})$ is attributed to dehydration, with loss of 1 and $1.5 \mathrm{H}_{2} \mathrm{O}$, respectively (Calcd. $=5.22 \%$, $7.41 \%$; $\mathrm{TG}=5.30 \%, 7.50 \%$ )

The anhydrous compound is stable up to $300{ }^{\circ} \mathrm{C}(\mathrm{Ni}, \mathrm{Zn})$ and above this temperature, the mass loss occurs in three consecutive steps between $300>1000(\mathrm{Ni}, \mathrm{Zn})$. The first two steps of mass loss occurs between 300 and $415{ }^{\circ} \mathrm{C}, 415-560{ }^{\circ} \mathrm{C}(\mathrm{Ni})$ and $300-370{ }^{\circ} \mathrm{C}, 370-560{ }^{\circ} \mathrm{C}$ (Zn), with losses of the $32,47 \%, 14,36 \%(\mathrm{Ni})$ and $21,82 \%, 32,14 \%(\mathrm{Zn})$, corresponding to endothermic peaks at $390{ }^{\circ} \mathrm{C}, 530^{\circ} \mathrm{C}(\mathrm{Ni})$ and $325{ }^{\circ} \mathrm{C}$, $520^{\circ} \mathrm{C}(\mathrm{Zn})$ attributed to the thermal decomposition and pyrolysis of the compounds.

The last step of mass loss in the TG curve of the nickel compound (555 > $1000{ }^{\circ} \mathrm{C} ; \mathrm{TG}=10,25 \%$ ), associated to the exothermic peak at $765^{\circ} \mathrm{C}$, is attributed to the pyrolysis and reaction of carbonaceous residue with nickel oxide, resulting to a partial reduction reaction of $\mathrm{Ni}_{\mathrm{x}} \mathrm{O}_{\mathrm{y}}$ to $\mathrm{Ni}^{\circ}$, As also observed for the cobalt and manganese compounds [19.20]. The EGA analysis in dynamic $\mathrm{N}_{2}$ atmosphere also shown the presence of $\mathrm{CO}_{2}$ up to temperature $765{ }^{\circ} \mathrm{C}$, see Fig. $5 \mathrm{~S}$ in the supplementary material. For the zinc compound, in pyrolysis condition, the mass loss up to $560^{\circ} \mathrm{C}$ suggest the formation of the $\mathrm{ZnO}$ and carbonaceous residue ( $\mathrm{TG}=61,46 \%$ ). The last mass loss occurs between 560 and $1000^{\circ} \mathrm{C}$, associated with and endotherm between 620 and $765{ }^{\circ} \mathrm{C}$, is attributed to reduction reaction of the $\mathrm{ZnO}$ to $\mathrm{Zn}^{00}$ by the carbonaceous residue and evaporation of $\mathrm{Zn}^{00}$ (boiling point $=907^{\circ} \mathrm{C}$ ) [21]. For both compounds with mass losses still being observed up to $1000{ }^{\circ} \mathrm{C}$.
The endo and exothermic peaks at 200 and $210{ }^{\circ} \mathrm{C}$, without mass loss in TG curve of zinc compound are attributed to melting followed by recrystallization, respectively (see supplementary material).

\subsubsection{Copper compound}

The TG-DTA curves are shown in Fig. 1(i). The first mass loss between 95 and $180^{\circ} \mathrm{C}$, corresponding to an endothermic peak at $170{ }^{\circ} \mathrm{C}$ is attributed to dehydration with loss of $2 \mathrm{H}_{2} \mathrm{O}$ (Calcd. $=9.69 \%$, $\mathrm{TG}=9.85 \%)$

The anhydrous compound is stable up to $250{ }^{\circ} \mathrm{C}$, and above this temperature, the mass losses occur in three steps, being the first one a fast process, followed by the last two slow processes, with mass losses still being observed up to $1000{ }^{\circ} \mathrm{C}$.

The steps that occur between 250 and $310{ }^{\circ} \mathrm{C}, 310-500{ }^{\circ} \mathrm{C}$, $570>1000{ }^{\circ} \mathrm{C}$ with losses of $56.10 \%, 4.81 \%, 5.87 \%$, corresponding to endothermic peaks at $290^{\circ} \mathrm{C}$ and $815^{\circ} \mathrm{C}$, are attributed to the thermal decomposition and pyrolysis of the compound.

\subsection{Differential scanning calorimetry (DSC)}

The DSC curves of the cobalt, nickel, copper and zinc compounds are shown in Fig. 2a-d.

These curves show endothermic and exothermic peaks in agreement the thermal events observed in the DTA curves up to $250{ }^{\circ} \mathrm{C}$. The endothermic peaks at $154^{\circ} \mathrm{C}(\mathrm{Ni}), 168^{\circ} \mathrm{C}(\mathrm{Cu})$ and $107^{\circ} \mathrm{C}(\mathrm{Zn})$ are attributed to dehydration. The endothermic peaks at $79^{\circ} \mathrm{C}$ for cobalt compound is attributed to reversible phase transformation, as suggested by cyclic DSC analysis (Fig. 1S), while the endothermic peak at $196{ }^{\circ} \mathrm{C}$ followed by an exothermic one at $207^{\circ} \mathrm{C}$ for zinc compound are 

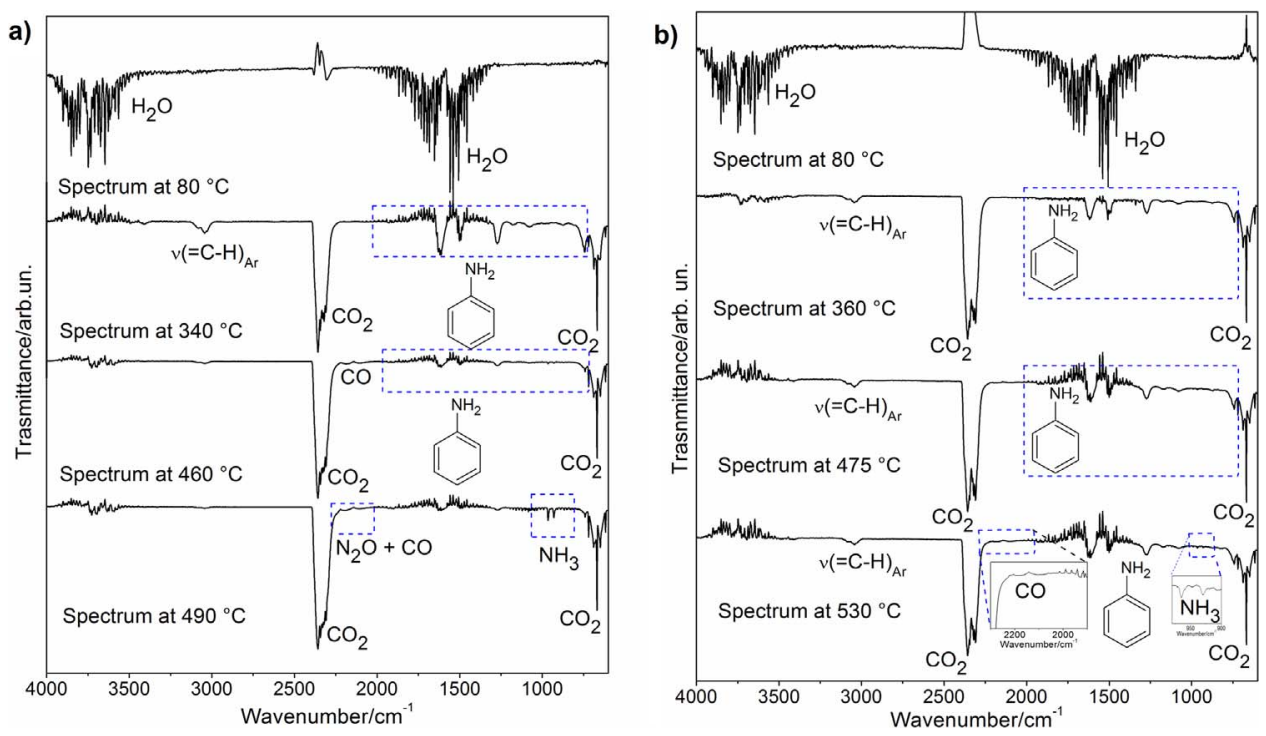

Fig. 3. FTIR spectra from the gaseous products evolved during the thermal decomposition of zinc compound in dry air (a) and $\mathrm{N}_{2}$ (b) atmospheres.

attributed to melting followed by recrystallization, respectively, confirmed by DSC-fotovisual System and PXRD of the sample heated at different temperatures (see video and Fig. 2S). The dehydration enthalpies found for the compounds were: $81.1(\mathrm{Ni}), 54.1(\mathrm{Cu}), 107.2(\mathrm{Zn})$ $\mathrm{kJ} \mathrm{mol}^{-1}$, and the phase transformation enthalpies were 21.0 (melting) and 12.5 (recrystallization) $\mathrm{kJ} \mathrm{mol}^{-1}$ for the zinc and $2.7 \mathrm{~kJ} \mathrm{~mol}^{-1}$ for the cobalt compound.

\subsection{Evolved gas analysis (EGA by TG/DSC-FTIR)}

The main gaseous products evolved during the thermal decomposition of the synthesized compounds were analyzed by EGA in both atmospheres (dry air and $\mathrm{N}_{2}$ ). The infrared spectra collected at different temperatures for the gaseous products released during the thermal decomposition (air) and pyrolysis $\left(\mathrm{N}_{2}\right)$ of the zinc compound are presented in Fig. 3a (air) and b $\left(\mathrm{N}_{2}\right)$. For the other compounds, the FTIR spectra are shown in the supplementary material.

The thermal decomposition in dynamic dry air and nitrogen atmospheres, of the compounds showed the released the gaseous products in three (anhydrous compounds) and four (hydrated compounds) main steps. For the hydrated compounds ( $\mathrm{Ni}, \mathrm{Cu}$ and $\mathrm{Zn}$ ), in both atmospheres the presence of bands between 3980 and $3351 \mathrm{~cm}^{-1}$ and $2225-1210 \mathrm{~cm}^{-1}$ in the spectrum collected (Fig. 3a and b) were related to the vibrational modes of water molecules, and are in agreement with the dehydration process.

In following steps of the thermal decomposition in dynamic dry air atmosphere, the main gaseous products identified were $\mathrm{CO}_{2}, \mathrm{CO}, \mathrm{NH}_{3}$, $\mathrm{N}_{2} \mathrm{O}$ and aniline for all the compounds, exception for cobalt and copper compounds. For these compounds, the EGA analysis showed no presence of $\mathrm{NH}_{3}$. The release of $\mathrm{CO}_{2}$ and $\mathrm{CO}$ are characterized by the presence of the bands in the FTIR spectra at $2356 \mathrm{~cm}^{-1}$ ( $\nu \mathrm{COO}$ ), $668 \mathrm{~cm}^{-1}$ ( $\left.\delta \mathrm{COO}\right), 2227-2037 \mathrm{~cm}^{-1}$. The bands in $3045 \mathrm{~cm}^{-1}$ $\left(v C-H_{a r}\right), \quad 1622 / 1510 \mathrm{~cm}^{-1} \quad\left(v C=C_{a r}\right), 1273 \mathrm{~cm}^{-1}\left(\nu C-N_{\text {amine }}\right)$, $1173-1085 \mathrm{~cm}^{-1}\left(\delta C C C_{a r}\right), 875 \mathrm{~cm}^{-1}\left(\beta C-H_{a r}\right) 746 \mathrm{~cm}^{-1}(\delta C C N)$ and 987 and $930 \mathrm{~cm}^{-1}(\delta N-H)$, and bands between 2250 and $2130 \mathrm{~cm}^{-1}\left(\mathrm{vN}_{2} \mathrm{O}\right.$ - asymmetricalandsymmetrical $)$ were assigned to the vibration modes of the groups present in aniline, $\mathrm{N}_{2} \mathrm{O}$ and $\mathrm{NH}_{3}$ molecules [7,16,22-24].

In dynamic nitrogen atmosphere, the gaseous products released during the pyrolysis of the anhydrous synthesized compounds were $\mathrm{CO}_{2}, \mathrm{CO}, \mathrm{NH}_{3}$ and Aniline for copper, nickel and zinc compounds. However, for the cobalt and manganese compounds were detected only $\mathrm{CO}_{2}, \mathrm{CO}$ and aniline, and $\mathrm{CO}_{2}$ and aniline, respectively. The gaseous products were identified by the presence of the bands previously described in the discussion of the FTIR spectra for the compounds analyzed by EGA in dynamic dry air atmosphere (see Fig. 3b and supplementary material).

\subsection{Powder X-ray diffraction (PXRD)}

The powder X-ray diffraction patterns (Fig. 4) show that all the compounds have a crystalline structure, without evidence for formation of isomorphous compounds. In addition, the degree of crystallinity also was analyzed for these compounds, and it follows the order $\mathrm{Mn}=\mathrm{Zn}>\mathrm{Ni}>\mathrm{Cu}>\mathrm{Co}$.

\subsection{Infrared spectroscopy (FTIR)}

The IR spectra show bands related to vibrational modes of H-pABA, Na-pABA and transition metal compounds in Fig. 5 and Table 2. For the

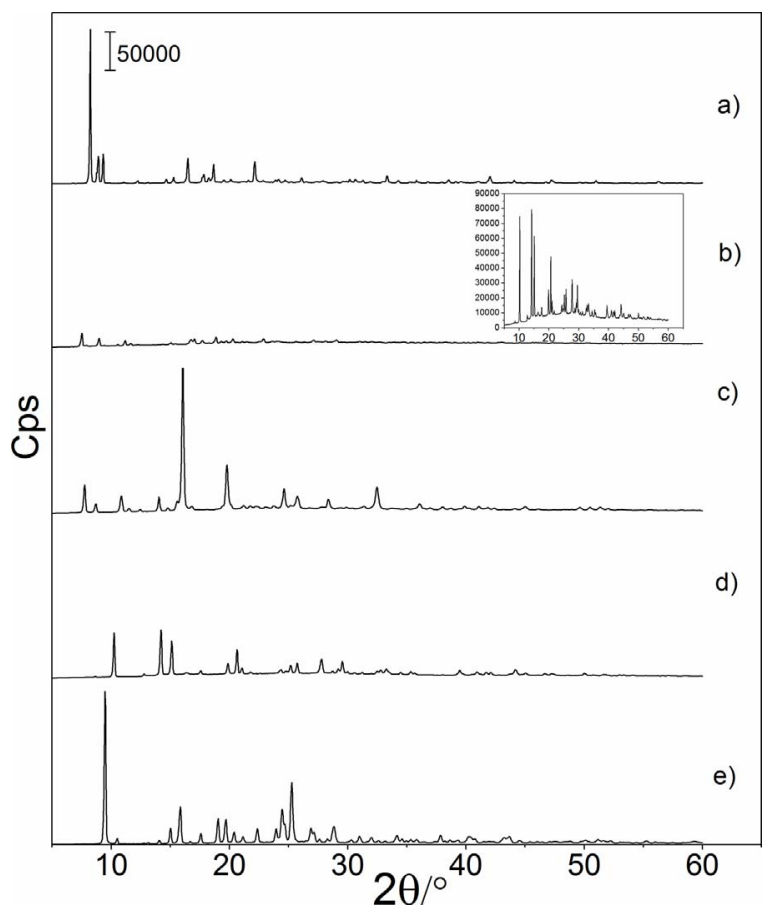

Fig. 4. X-ray powder diffractograms: (a) $\mathrm{Mn}(\mathrm{L})_{2}$; (b) $\mathrm{Co}(\mathrm{L})_{2}$; (c) $\mathrm{Ni}(\mathrm{L})_{2} \cdot \mathrm{H}_{2} \mathrm{O}$; (d) $\mathrm{Cu}$ $(\mathrm{L})_{2} \cdot 2 \mathrm{H}_{2} \mathrm{O}$; (e) $\mathrm{Zn}(\mathrm{L})_{2} \cdot 1.5 \mathrm{H}_{2} \mathrm{O}$. 


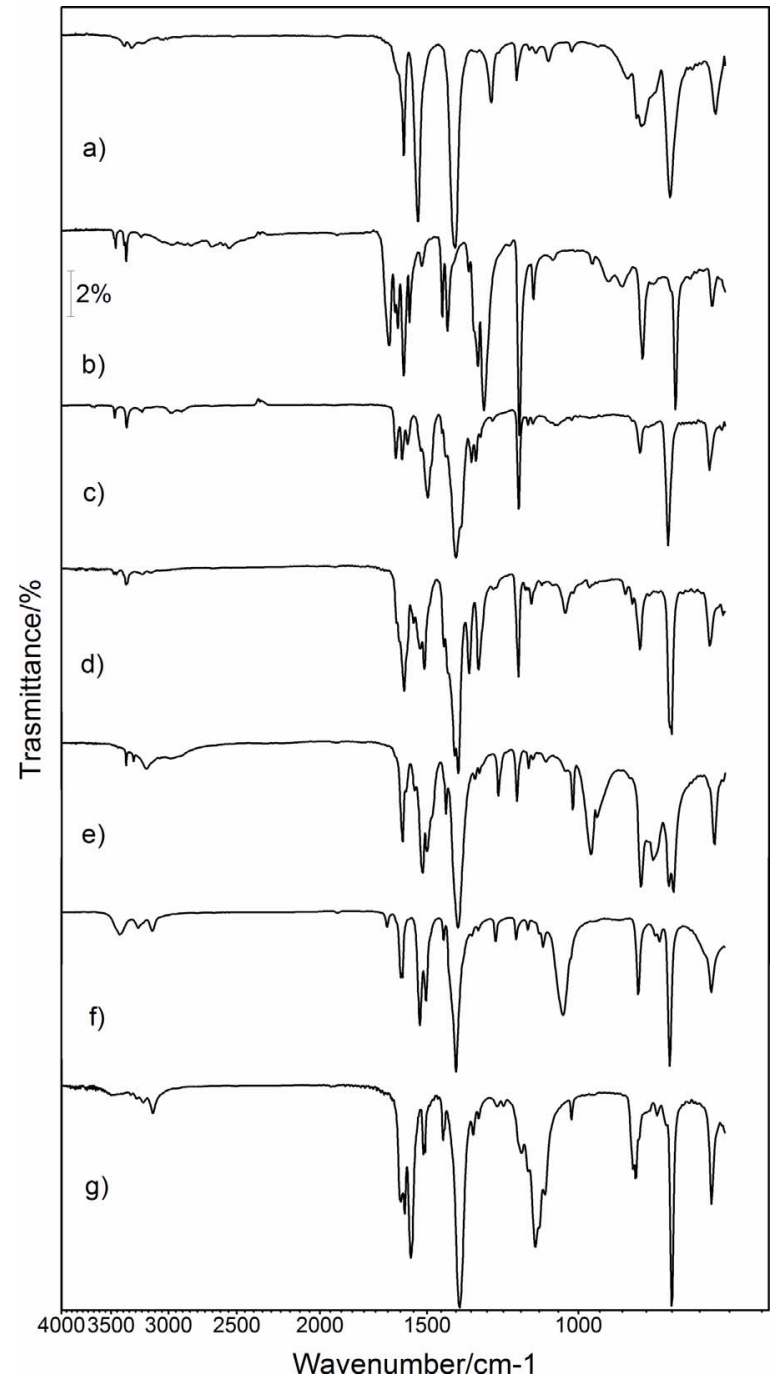

Fig. 5. FTIR spectra of (a) Na-pABA, (b) $\mathrm{H}-\mathrm{pABA}$, (c) $\mathrm{Mn}(\mathrm{L})_{2}$, (d) $\mathrm{Ni}(\mathrm{L})_{2} \cdot \mathrm{H}_{2} \mathrm{O}$, (e) $\mathrm{Cu}$ (L) $)_{2} \cdot 2 \mathrm{H}_{2} \mathrm{O}$ and (f) $\mathrm{Zn}(\mathrm{L})_{2} \cdot 1.5 \mathrm{H}_{2} \mathrm{O}$.
H-pABA, the IR spectrum shows bands related with vibrational modes of the acid dimeric form $(\mathrm{vC}=\mathrm{O})$ in $1662 \mathrm{~cm}^{-1}$ and its amino group $\left(-\mathrm{NH}_{3}\right)$ in $3460 \mathrm{~cm}^{-1}\left(v_{a s} N-H\right), 3364 \mathrm{~cm}^{-1}\left(v_{s} N-H\right), 3381 \mathrm{~cm}^{-1}$ (harmonic band $\mathrm{NH}_{3}$ group), $1623 \mathrm{~cm}^{-1}(\delta N-H)$ and $1310 \mathrm{~cm}^{-1}$ $(v C-N)[16,22,24-26]$.

For the Na-pABA and synthesized compounds, the band in $1662 \mathrm{~cm}^{-1}$ was not observed. Nevertheless, it is observed the presence of strong bands attributed to the asymmetrical and symmetrical frequencies of the carboxylate group. The difference between asymmetrical and symmetrical stretching $\left(\Delta \nu=\nu_{\mathrm{as}} \mathrm{COO}^{-}-\nu_{\text {sym }} \mathrm{COO}^{-}\right)$of the carboxylate group observed for the Na-pABA was compared with those observed for the synthesized compounds (see Table 2), and it was possible to suggest three different coordination modes of carboxylate group with the metal ions [16,22,27-29].

For the cobalt, nickel and copper compounds the IR spectra show two asymmetrical and one (Ni, $\mathrm{Cu}$ ) and two (Co) symmetrical carboxylate stretches (see Table 2 and Fig. 5), indicating the existence of two different coordination modes of the carboxylate for these compounds [30]. For these compounds, the $\Delta \nu$ observed was similar $(\Delta \nu=148-137)$ and lower $(\Delta \nu=120-117)$ than the $\Delta \nu$ values observed for the sodium salt $(\Delta \nu=140)$, indicating that the coordination of the carboxylate group occurs in bidentate bridging and/or chelating mode [27].

For the $\mathrm{Zn}(\mathrm{pABA})_{2} \cdot 1.5 \mathrm{H}_{2} \mathrm{O}$ the IR spectrum shows large separation of the asymmetrical and symmetrical carboxylate stretches $(\Delta \nu=192)$, greater than the observed for the sodium salt, see Table 2 . These results suggest that the interaction of the carboxylate group to the zinc ion occurs in the unidentate form [27].

The bands related to the carboxylate group in the FTIR spectrum of the manganese compound, unlike that occurring for the zinc compound, showed a decrease of the separation. In this case, the $\Delta \nu$ value suggests that the carboxylate group coordinates to the metal ion in the bidentate chelate mode, see Table 2 and Fig. 5 [27].

The vibrational modes of the amino group of the synthesized compounds were also analyzed and compared with H-pABA and sodium salt. The results showed changes in the absorption wavenumbers of this group for some of the metal compounds. According to the changes observed in the wavenumbers and intensity in which the bands referring to the amino group appear in the FTIR spectra of the synthesized compounds (see Table 2 and Fig. 5) it may be suggested that for the

Table 2

Main vibrational data (FTIR) for the p-aminobenzoic acid, their sodium salt and compounds synthesized.

\begin{tabular}{|c|c|c|c|c|c|c|c|}
\hline Assignment [23-26] & H-pABA & $\mathrm{Na}(\mathrm{L}) \cdot 0.5 \mathrm{H}_{2} \mathrm{O}$ & $\mathrm{Mn}(\mathrm{L})_{2}$ & $\mathrm{Co}(\mathrm{L})_{2}$ & $\mathrm{Ni}(\mathrm{L})_{2} \cdot \mathrm{H}_{2} \mathrm{O}$ & $\mathrm{Cu}(\mathrm{L})_{2} \cdot 2 \mathrm{H}_{2} \mathrm{O}$ & $\mathrm{Zn}(\mathrm{L})_{2} \cdot 1 \cdot 5 \mathrm{H}_{2} \mathrm{O}$ \\
\hline$\nu$ asNH ${ }_{2}$ & $3460_{w}$ & $3377_{\mathrm{w}}$ & $3469_{w}$ & $3452_{\mathrm{vw}}$ & $3365_{w}$ & $3225_{w}$ & $3265_{\mathrm{vw}}$ \\
\hline$\nu \mathrm{sNH}_{2}$ & $3363_{\mathrm{w}}$ & $3315_{\mathrm{w}}$ & $3359_{\mathrm{w}}$ & $3366_{w}$ & $3299_{\mathrm{w}}$ & $3134_{w}$ & $3212_{\mathrm{vw}}$ \\
\hline$\nu \mathrm{OH}$ & $3000-3250_{w}$ & $3223_{\mathrm{w}}$ & & & $3184_{w}$ & $3420_{w}$ & $3500_{w}$ \\
\hline$\nu \mathrm{CH}$ & $3010-3050_{w}$ & $3045 / 3012_{\mathrm{w}}$ & $2988 / 2900_{w}$ & & $3074 / 2988_{\mathrm{vw}}$ & & \\
\hline $\mathrm{N}-\mathrm{H} \cdots \mathrm{O} / \mathrm{O}-\mathrm{H} \cdot \mathrm{N}$ & $2300-3000_{\mathrm{w}}$ & & & & & & \\
\hline$\nu \mathrm{C}=\mathrm{O}$ & $1663_{\mathrm{s}}$ & & & & & & \\
\hline$\delta \mathrm{NH}_{2}$ & $1623_{\mathrm{m}}$ & $1598_{\mathrm{m}}$ & $1633_{\mathrm{m}}$ & & & & \\
\hline$\nu \mathrm{C}=\mathrm{C}$ & $1598_{\mathrm{s}}$ & & $1605_{\mathrm{m}}$ & $1596_{s}$ & $1603 \mathrm{~s}$ & $1610 / 1603_{\mathrm{m}}$ & $1610_{\mathrm{s}}$ \\
\hline$\nu \mathrm{C}=\mathrm{C}$ & $1574_{\mathrm{m}}$ & & $1582_{\mathrm{m}}$ & & & & $1593_{\mathrm{s}}$ \\
\hline$\nu \mathrm{asCOO}^{-}$ & & $1538_{\mathrm{vs}}$ & $1498_{\mathrm{s}}$ & $1528 / 1512_{\mathrm{s}}$ & $1519 / 1502_{\mathrm{s}}$ & $1530 / 1505_{s}$ & $1567_{s}$ \\
\hline$\nu \mathrm{C}=\mathrm{C}$ & $1522_{\mathrm{w}}$ & & & & & & $1515_{\mathrm{m}}$ \\
\hline$\nu \mathrm{C}=\mathrm{C}$ & $1441_{\mathrm{m}}$ & & & & & & $1437_{\mathrm{w}}$ \\
\hline$\delta \mathrm{OH}$ & $1421_{\mathrm{m}}$ & & & & & & \\
\hline$\nu \mathrm{SCOO}^{-}$ & & $1398_{\mathrm{vs}}$ & $1389_{\mathrm{vs}}$ & $1394 / 1380_{\mathrm{vs}}$ & $1382_{\mathrm{vs}}$ & $1388_{\mathrm{vs}}$ & $1375_{\mathrm{vs}}$ \\
\hline$\nu \mathrm{C}-\mathrm{N}$ & $1310_{s}$ & $1264_{\mathrm{m}}$ & $1316_{\mathrm{m}}$ & $1308_{\mathrm{s}}$ & $1320_{\mathrm{vw}}$ & $1308_{\mathrm{vw}}$ & $1326_{w}$ \\
\hline$\nu \mathrm{C}-\mathrm{OH}$ & $1289_{\mathrm{vs}}$ & & & & & & \\
\hline Sout $\mathrm{NH}_{2}$ & $1072_{\mathrm{vw}}$ & $1084_{\mathrm{vw}}$ & $1066_{w}$ & & $1092_{\mathrm{vw}}$ & $1099_{\mathrm{w}}$ & \\
\hline$\delta \mathrm{CH}$ & & $1018_{\mathrm{vw}}$ & & & $1015_{\mathrm{m}}$ & & $1018_{\mathrm{w}}$ \\
\hline 8out $\mathrm{CH}$ & $842_{\mathrm{m}}$ & $845_{m}$ & $848_{m}$ & & $846_{s}$ & $851_{\mathrm{s}}$ & $863_{\mathrm{m}}$ \\
\hline sout $\mathrm{CH}$ & $770_{\mathrm{vs}}$ & $782_{\mathrm{vs}}$ & $787_{\mathrm{vs}}$ & & $785_{\mathrm{vs}}$ & $782_{\mathrm{vs}}$ & $778_{\mathrm{vs}}$ \\
\hline$\delta \mathrm{C}-\mathrm{C}-\mathrm{C}$ & $699_{w}$ & $692_{\mathrm{m}}$ & $703_{\mathrm{m}}$ & & $695_{\mathrm{m}}$ & $700_{\mathrm{m}}$ & $700_{\mathrm{m}}$ \\
\hline$\Delta v_{a} \mathrm{COO}_{-}-v_{\mathrm{COO}}$ & & 140 & 109 & $148 / 118$ & $137 / 120$ & $142 / 117$ & 192 \\
\hline
\end{tabular}

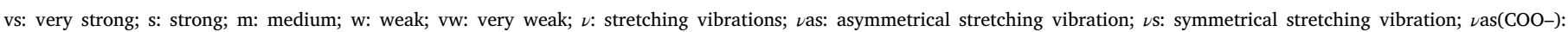
asymmetric carboxyl stretching vibration; $\nu$ s(COO-): symmetric carboxyl stretching vibration; $\delta$ : in plane bending vibration. $\delta$ out: out of plane bending vibration. 
nickel, copper and zinc compounds the amino group participates in the metal-ligand interaction $[16,22]$.

However, no significant changes were observed in the wavenumber in which the bands of the amino group appear in the FTIR spectrum of the cobalt and manganese compounds (Table 2) indicating that the amino group do not participate in the metal-ligand interaction for these compounds.

\section{Conclusion}

By TG-DTA, complexometry and elemental analysis results it was possible to establish the general formula $\mathrm{M}(\mathrm{L})_{2} \mathrm{nH}_{2} \mathrm{O}$ for the synthesized compounds, where $\mathrm{M}$ represents $\mathrm{Mn}, \mathrm{Co}, \mathrm{Ni}, \mathrm{Cu}$ and $\mathrm{Zn}, \mathrm{L}$ is paminobenzoate and $n=0$ (Mn, Co), $1(\mathrm{Ni}), 1.5(\mathrm{Zn}), 2(\mathrm{Cu})$.

The TG-DTA results provided information on the composition, dehydration, thermal stability, thermal decomposition, phase transformation, as well as the gaseous products that evolved during the thermal decomposition of these compounds in pyrolysis and oxidative conditions. The main gaseous products released during thermal decomposition and pyrolysis of the complexes were identified by EGA as $\mathrm{CO}, \mathrm{CO}_{2}$, $\mathrm{N}_{2} \mathrm{O}, \mathrm{NH}_{3}$ and aniline in air atmosphere and $\mathrm{CO}, \mathrm{CO}_{2}, \mathrm{NH}_{3}$ and Aniline in nitrogen atmosphere, in addition to water for the hydrated compounds.

The DSC curves in nitrogen atmosphere provided information on the phase transformation and dehydration enthalpies for the compounds, as well as enabled to determine the reversibility of phase transition phenomena. The micrographs obtained during heating in DSC curves by DSC photovisual system confirmed the physical phenomena observed in zinc compound.

The powder X-ray patterns showed that all the compounds have a crystalline structure, without evidence of the formation of isomorphous compounds.

IR spectroscopic data suggest different modes of coordination for the synthesized compounds, being bidentate bridging and/or chelate for $\mathrm{Co}, \mathrm{Ni}$ and $\mathrm{Cu}$, unidentate for $\mathrm{Zn}$ and bidentate chelate for $\mathrm{Mn}$ compound.

\section{Acknowledgments}

The authors thanks CPID/CDMF, FAPESP (Proc. $n^{\circ}$ 2013/09022-7, Proc. $n^{\circ}$. 2013/07296-2 and Proc. $n^{\circ}$ 2017/14936-9), CNPq (Proc. 421469/2016-1), and CAPES foundations (Brazil) for financial support.

\section{Appendix A. Supplementary data}

Supplementary data associated with this article can be found, in the online version, at http://dx.doi.org/10.1016/j.jaap.2017.10.002.

\section{References}

[1] British Pharmacopoeia Monographs: Medicinal and Pharmaceutical Substances, Aminobenzoic Acid, The Stationery Office, London, 2009.

[2] R.M.E. Richards, D.K.L. Xing, The effect of p-aminobenzoic acid on the up take of thymidine and uracil by Escherichia coli, Int. J. Pharm. 116 (1995) 217-221.

[3] S.I. Akberova, New biological properties of p-aminobenzoic acid, Biol. Bull. 29 (2002) 390-393.

[4] J.A. Teixeira, A.B. Siqueira, Thermal and spectroscopic characterization, antioxidant evaluation and pyrolysis of losartan with some bivalent metals, J. Anal. Appl. Pyrolysis 117 (2016) 17-24..

[5] B.R. Srinivasan, S.C. Sawant, Thermal and spectroscopic characterization of $\mathrm{Mg}(\mathrm{II})$ complexes of nitro-substituted benzoic acids, Thermochim. Acta 402 (2003) 45-55.

[6] A.B. Siqueira, C.T. Carvalho, E.Y. Ionashiro, G. Bannach, E.C. Rodrigues, M. Ionashiro, Synthesis, characterization and thermal behavior of solid 2-methoxybenzoates of trivalent metals, J. Therm. Anal. Calorim. 92 (2008) 945-951.

[7] A.L.C.S. Nascimento, F.J. Caires, D.J.C. Gomes, A.C. Gigante, M. Ionashiro, Thermal behavior of nicotinic acid, sodium nicotinate and its compounds whit some bivalents transition metal ions, Thermochim. Acta 575 (2014) 212-218.

[8] H. Tan, C. Ma, L. Chen, F. Xu, S. Chen, L. Wang, Nanoscaled lanthanide/nucleotide coordination polymer for detection of an anthrax biomarker, Sens. Actuators. B, Chem. 190 (2014) 621-626.

[9] J. Shen, L. Zhao, G. Han, Lanthanide-doped up converting luminescent nanoparticle platforms for optical imaging-guided drug delivery and therapy, Adv. Drug Delivery Rev. 65 (2013) 744-755.

[10] D.A. Gálico, M.G. Lahoud, M.R. Davolos, R.C.C. Frem, T.F.C. Fraga-Silva, J. Venturini, G. Bannach, Spectroscopic, luminescence and in vitro biological studies of solid ketoprofen of heavier trivalent lanthanides and yttrium(III), J. Inorg. Biochem. 140 (2014) 160-166.

[11] A. Aragón-Muriel, M. Camprubi-Robles, E. González-Rey, A. Salinas-Castillo, A. Rodrígues-Diéguez, S. Gómez-Ruiz, D. Polo-Cerón, Dual investigation of lanthanide complex with cinnamate and phenylacetate ligands: study of the cytotoxic properties and the catalytic oxidation of styrene, Polyhedron 80 (2014) 117-128.

[12] D.A. Gálico, B.B.C. Holanda, R.B. Guerra, A.O. Legendre, D. Rinaldo, O. Treu-Filho, G. Bannach, Thermal and spectroscopic studies on solid ibuprofen complexesof lighter trivalente lanthanides, Thermochim. Acta 575 (2014) 226-232.

[13] D.A. Gálico, B.B.C. Holanda, G.L. Perpétuo, E. Schnitzler, O. Treu-Filho, G. Bannach, Thermal and spectroscopic studies on solid ketoprofen of lightertrivalente lanthanides, J. Therm. Anal. Calorim. 108 (2012) 371-379.

[14] D.-H. Hu, W. Huang, S.-H. Gou, J.-L. Fang, H.-K. Fun, Synthesis characterization and magnetic properties of a dinuclear complex $\left[\mathrm{Cu}\left(2,2^{\prime}\right.\right.$-bpy)(HL)(L)]2(NO3) $2 \cdot(\mathrm{H} 2 \mathrm{O}) 3 / 2$ and a $1 \mathrm{D}$ chain $\left\{\left[\mathrm{Cu}\left(2,2^{\prime}\right.\right.\right.$-bpy) $\left(4,4^{\prime}\right.$-bpy) $\left.\left.1 / 2(\mathrm{~L})\right](\mathrm{ClO} 4) \cdot(1 / 2 \mathrm{H} 2 \mathrm{O})\right\} \mathrm{n}$ (L is p-aminobenzoate), Polyhedron 22 (2003) 2661-2667.

[15] Z. Rzaczynska, W. Brzyska, Complexes of Y La, and lanthanides with m-aminobenzoic acid, Mon. Chem. 120 (1989) 231-236.

[16] J.A. Teixeira, W.D.G. Nunes, T.A.D. Colman, A.L.C.S. do Nascimento, F.J. Caires, F.X. Campos, D.A. Gálico, M. Ionashiro, Thermal and spectroscopic study to investigate p-aminobenzoic acid, sodium p-aminobenzoate and its compounds with some lighter trivalent lanthanides, Thermochim. Acta 624 (2016) 59-68.

[17] H.A. Flaschka, EDTA Titrations and Introduction to Theory and Practice, 2nd ed., Press Oxford, Pergamon, 1964

[18] M. Ionashiro, C.A.F. Gramer, J. Zuanon Netto, Titulac ão complexometrica delantanideos e ítrio, Ecl. Quím. 8 (1983) 29-32.

[19] F.J. Caires, D.J.C. Gomes, A.C. Gigante, L.S. Lima, C.T. Carvalho, M. Ionashiro, Thermal behavior of malonic acid, sodium malonate and its compounds with some bivalent transition metal ions in dynamic $\mathrm{N}_{2}$ and $\mathrm{CO}_{2}$ atmospheres, Braz. J. Therm. Anal. 2 (1) (2013) 12-16.

[20] E.R. Stobbe, B.A. de Boer, J.W. Geus, The oxidation and reduction behaviour of manganese oxides, Catal. Today 47 (1999) 161-167.

[21] D.J.C. Gomes, F.J. Caires, L.S. Lima, A.C. Gigante, M. Ionashiro, Synthesis, characterization and thermal study of solid mandelate of some bivalent transition metal ions in $\mathrm{CO}_{2}$ and $\mathrm{N}_{2}$ atmospheres, J. Therm. Anal. Calorim. 111 (2013) 57-62.

[22] J.A. Teixeira, W.D.G. Nunes, A.L.C.S. do Nascimento, T.A.D. Colman, F.J. Caires, D.A. Gálico, M. Ionashiro, Synthesis, thermoanalytical, spectroscopic study and pyrolysis of solid rare earth complexes (Eu, Gd, Tb and Dy) with p-aminobenzoic acid, J. Anal. Appl. Pyrolysis 121 (2016) 267-274.

[23] M. Mukherjee, B. Bandyopadhyay, P. Biswas, T. Chakraborty, Amine inversion effects on the IR spectra of aniline in the gas phase and cold inert gas matrixes, Indian J. Phys. 86 (2012) 201-208.

[24] R.M. Silverstein, F.X. Webster, Spectrometric Identification of Organic Compounds, 6th ed., Wiley, New York, 1998.

[25] M. Samsonowicz, T. Hrynaszkiewicz, R. Swislocka, E. Regulska, W. Lewandowski, Experimental and theoretical I.R. raman, NMR, spectra of 2-3-and 4-aminobenzoic acids, J. Mol. Struct. 744-747 (2005) 345-352.

[26] R. Swislocka, M. Samsonowicz, E. Regulska, W. Lewandowski, Molecular Structure of 4-aminobenzoic acid salts with alkali metals, J. Mol. Struct. $792-793$ (2006) $227-238$

[27] G.B. Deacon, R.J. Phillips, Relationships between the carbon-oxygen stretching frequencies of carboxylato complexes and the type of carboxylate coordination, Coord. Chem. Rev. 33 (1980) 227-250.

[28] K. Nakamoto, Infrared and Raman Spectra of Inorganic and Coordination Compounds, fifth ed., Wiley, New York, NY, USA, 1997.

[29] G. Versanyi, Assignments for Vibrational Spectra of 700 Benzene Derivatives, Akademiai Kiado, Budapest, Hungary, 1973.

[30] V. Zelenák, Z. Vargová, K. Gyoryová, Correlation of infrared spectra of zinc(II) carboxylates with their structures, Spectrochim. Acta, Part A 66 (2007) 262-272. 